Brit. J. industr. Med., 1959, 16, 216.

\title{
THE ACUTE TOXIC EFFECTS OF BLACK SMOKE
}

\author{
BY
}

\author{
R. E. PATtle, G. D. WEDD, and F. BURGESS \\ From the Chemical Defence Experimental Establishment, Porton Down, Salisbury, Wilts
}

(RECEIVED FOR PUBLICATION SEPTEMBER 3, 1958)

\begin{abstract}
Few experiments have been conducted on the toxicity of solid carbonaceous combustion products. In order to obtain an estimate of the toxicity of black smoke which could be compared with similar estimates for other pollutants, the median dosage to death, $(\mathrm{Ct}) \mathrm{D} \mathrm{50}$, has been determined for smoke from burning tetrahydronaphthalene administered to guinea-pigs and mice. Values ranging from $147,000 \mathrm{mg}$. min. $/ \mathrm{m}^{3}$ to $351,000 \mathrm{mg}$. min. $/ \mathrm{m}^{3}{ }^{3}$ were obtained at concentrations between $714 \mathrm{mg} . / \mathrm{m} .{ }^{3}$ and $1,140 \mathrm{mg} . / \mathrm{m} .^{3}$. Animals allowed to associate protected one another to some extent, probably owing to their fur acting as a filter.

In mice the cause of death appears to be blockage of the air passages; deaths after removal from the smoke are unusual. In guinea-pigs haemorrhagic lesions are caused, and delayed deaths are commoner.

The action of smoke on rats resembles its action on mice.

It is pointed out that tetralin smoke is considerably more toxic to animals than is sulphur dioxide in the same concentration. This finding is discussed in relation to atmospheric pollution.
\end{abstract}

Black smoke is an atmospheric pollutant which attracts a good deal of attention. The suspended matter in city air may consist of, say, $1.0 \mathrm{mg} . / \mathrm{m}^{3}$ of combustible matter and $0.2 \mathrm{mg} . / \mathrm{m}^{3}$ of ash. The combustible matter consists mainly of carbon "tarry matter", i.e., matter insoluble in carbon disulphide, and is present to the extent of $3 \%$ to $5 \%$ of the suspended solids (Meetham, 1952). The mass median diameter of the particles is of the order $0.5 \mu$ to $1 \mu$; those particles more than $1 \mu$ across are mainly mineral, and those smaller than this are carbonaceous (Cartwright, Nagelschmidt, and Skidmore, 1956).

Experiments on the toxicity of solid carbonaceous combustion products have been few, and we have found no evidence in the literature of their lethal potentiality. Claisse and Josué (1897) studied anthracosis in animals exposed to unspecified but not lethal dosages of smoke from oil of turpentine (mainly $\mathrm{C}_{10} \mathrm{H}_{16}$ ) burning in a lamp. Vintinner and Baetjer (1951) exposed rats to the products of combustion of pulverized coal (mean concentration $57 \mathrm{mg} . / \mathrm{m}^{3}$; maximum dosage $4,200,000 \mathrm{mg}$. $\left.\mathrm{min} . / \mathrm{m}^{3}\right)$. There were no fatalities. The mass median diameter of the particles was probably large, as more than half the aerosol could be removed by filtration through steel wool. Pattle and Burgess (1957) reported exposures of mice to kerosene smoke
(354 mg./m. ${ }^{3}$; dosage $\left.106,200 \mathrm{mg} . \mathrm{min} . / \mathrm{m} .^{3}\right)$, without fatalities.

It was desired to obtain an estimate of the toxicity of black smoke which could be compared with similar estimates for other pollutants. It was evident that this would require a very high concentration of smoke, such as can conveniently be produced by burning tetralin (tetrahydronaphthalene, $\mathrm{C}_{10} \mathrm{H}_{12}$ ). The present work recounts experiments with this smoke; long-term observations on the survivors of these and other experiments are still in progress.

\section{Methods}

Production of Tetralin Smoke.-The smoke was produced by burning tetralin in an ordinary hurricane lamp (wick $13 \mathrm{~mm}$. wide) with the glass and upper part removed. It gives a very smoky flame, and has the right flash-point for burning in this type of lamp; the combustion products are not irritant and have a faint smell of naphthalene. The consumption of tetralin was measured by weighing the lamp before and after the experiment; the fraction of the carbon content of the tetralin which was converted to smoke varied from $5 \%$ to $11 \%$. The causes of this variation are not clear; it is important as it affects the concentration of smoke which can be obtained without overheating the chamber.

Exposure of Animals to the Smoke.-The animals were contained in cages within a chamber of 1101 . capacity in which the lamp also stood, and 20 or $251 . / \mathrm{min}$. of air 
was blown into the top of the chamber through a tube $6 \mathrm{~mm}$. in diameter; it thus entered with a velocity high enough $(1.2$ or $1.5 \mathrm{~m}$./ $/ \mathrm{sec}$.) to give adequate stirring, and in quantity sufficient to prevent environmental anoxia. The chamber was opened every $30 \mathrm{~min}$., when the animals were inspected and the relative positions of the cages were changed. The time at which each animal was found dead was noted.

The temperature in the chamber was kept at $29^{\circ} \mathrm{C}$. or less by adjusting the wick of the lamp, so that the animals should not suffer from heat stroke. In experiment 4 the incoming air was cooled in ice so that a larger flame could be used without overheating.

In most of the experiments the animals were each kept in a separate small cage or compartment of a larger one, as it was thought that if they were allowed to associate they would protect one another. In some cases, however, a whole batch was placed in one cage. In some experiments the exposure was continued until all the animals in a batch had died; in others, batches were withdrawn while there were still survivors, so that the likelihood of delayed deaths could be assessed and the long-term effects of the exposure could be observed. The details of each experiment are recorded in Table 1.

Sampling the Smoke.-The concentration of the smoke was determined by sampling on a Whatman No. 1 filter paper, using a $1 \mathrm{l} / \mathrm{min}$. critical orifice downstream to control the flow; the paper and deposit did not significantly affect the flow rate. The deposit on the paper was weighed, using a tared filter paper as counterweight. The filter paper was changed every $30 \mathrm{~min}$., but otherwise sampling was continuous; the mean concentration over each half-hour, including the times when the chamber was open for inspection, was thus recorded.

On removal from the chamber and exposure to the air of the balance room the smoke deposit lost about $30 \%$ of its weight within two hours. Oven-drying at $90^{\circ} \mathrm{C}$. removed another $10 \%$. All the recorded weights were taken after at least two hours' equilibration of the smoke deposit with the room atmosphere.

The content of tarry matter was determined by extracting a known weight of smoke deposit with carbon disulphide and weighing the tar thus obtained.

Definition of $(\mathbf{C t}) \mathrm{D}$ 50.-When a toxic agent produces effects which are not usually delayed, it is possible to get, with a given number of animals, a more accurate measure of the toxicity than can be obtained by measuring the $50 \%$ lethal dosage, or $\mathrm{L}(\mathrm{Ct}) 50$. This measure (Pattle and Burgess, 1957), the "dosage to $50 \%$ deaths" or (Ct)D 50, is defined as the dosage which has been received by the survivors of a batch of animals, all of which have been continuously exposed to a toxic agent, at the time at which $50 \%$ of the original batch have succumbed to the exposure.

To measure this, a batch is exposed to a more or less uniform concentration of a toxic agent, and the time at which each animal dies is noted. From the known concentration the dosage to death, $(\mathrm{Ct}) \mathrm{D}$, of each animal is calculated, and the individual $(\mathrm{Ct}) \mathrm{Ds}$ are treated statistically to obtain a value for the (Ct)D 50 and other data.
For the greatest accuracy, the experiment should be continued until all the animals have been killed. If the toxic agent is one which rarely causes delayed deaths, the $(\mathrm{Ct}) \mathrm{D} 50$ will be nearly equal to the $\mathrm{L}(\mathrm{Ct}) 50$; this is the case with black smoke acting on mice. For agents such as phosgene, which commonly produce delayed death, measurements of the $(\mathrm{Ct}) \mathrm{D} 50$ would be of less value.

Statistical Methods of Bliss (1937).-When all the animals in an experiment died, each individual animal was assumed to have died at the geometric mean of the dosages calculated for the last time at which the chamber was opened before, and for the first time it was opened after, the animal died. The logarithms of these dosages were treated as being distributed normally and the mean, its standard error, and the slope of the probit of kill against log. dosage were calculated; the last quantity was corrected for grouping.

After experiments in which several animals died, but left survivors, the probit of kill was plotted against the log. dosage for the time at which each animal was found dead; good straight lines were obtained. From these the $\log$. $(\mathrm{Ct}) \mathrm{D} 50$ and slope were read off. The standard error of the $\log$. $(\mathrm{Ct}) \mathrm{D} 50$ was calculated by the Bliss formulae, which allow for the increase in error caused by the truncation. The slope was corrected for grouping. No further corrections were applied.

Histological Methods.-Organs were fixed in formol saline and embedded in paraffin wax. Sections were then cut and were stained with haematoxylin and eosin.

\section{Results}

Toxicity of Black Smoke.-The results of four experiments with tetralin smoke are given in Table 1. It will be noted that of 28 deaths in those batches of mice which were withdrawn before they had all died, only one $(3.6 \%)$ took place after the end of the exposure. In experiment 3 , however, of a batch of 10 guinea-pigs which were alive when the exposure was terminated, three died during the subsequent 22 hours.

A number of other exposures of animals to smoke from burning kerosene, from burning coal distillates, and from a diesel engine, have also been carried out. In some of these up to 20 p.p.m. of sulphur dioxide accompanied the smoke. The results have been in accord with those of the experiments recorded in Table 1.

Pathological Findings.-Mice which had died from the acute effects of black smoke showed at necropsy blackening of the lungs, which was especially prominent when a cut surface was viewed. There was no sign of oedema or of widespread atelectasis, but congestion was often marked. The trachea was also blackened and often appeared to be blocked by sooty liquid. Soot was found in the nasal passages and the oesophagus.

Microscopically the absence of oedema was con- 
TABLE 1

ACUTE TOXICITY OF TETRALIN SMOKE

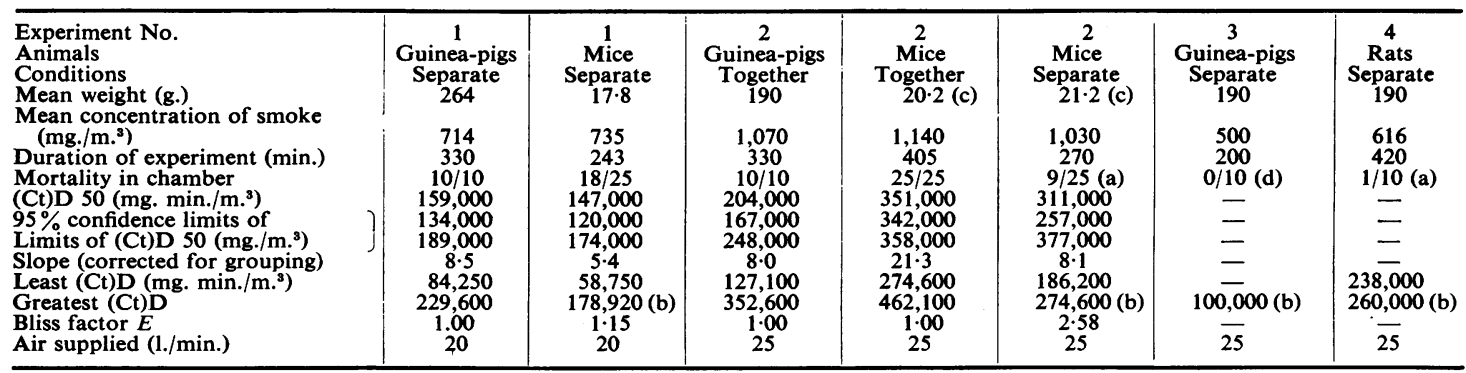

(a) One further animal died 5 minutes after removal from chamber.

(b) Dosage at which survivors were removed.

(c) The two batches had been separated by randomization three days beforehand.

(d) Three animals died within 22 hours of removal from the chamber.

firmed and the smaller bronchi appeared to be blocked by soot. The liver, adrenals, and kidneys were normal.

In rats the picture was similar, save that the trachea was clearer. The failure of the lungs to collapse when the chest was opened was very marked.

A different picture was found in guinea-pigs, both in those which had died during exposure and in those which died later. The lungs did not collapse on removal from the body. There were numerous haemorrhagic, atelectatic patches; these were about $3 \mathrm{~mm}$. across in the animals which died earliest, and gave place to larger haemorrhagic areas in those which survived the longest. The intervening areas were white and emphysematous, but a cut surface showed gross blackening of the lung. The patchwork of consolidated and emphysematous areas often resembled that produced in guinea-pigs by inhalation of sulphuric acid mist (Pattle, Burgess, and Cullumbine, 1956). The soot was found in the nasal passages but not in the trachea. The stomach contents were black; in some cases the stomach showed petechial haemorrhages. Microscopically the lungs showed oedema, emphysema, and some haemorrhagic consolidation.

The atelectatic areas could be re-inflated, and bubbles squeezed from the re-inflated portion resembled in their surface properties bubbles obtained from normal lung, it being thus inferred that the characteristic lining substance of the alveoli (Pattle, 1958) was still present in the atelectatic regions. Carboxyhaemoglobin was sought for in the dead animals by Lovibond's method, in which the colour of suitably diluted blood is compared with the colour of a standard series of glass discs; no trace of it was found.
Filtration of the Smoke by Fur.-As mentioned below, animals allowed to associate resisted the smoke better than animals in individual cages. The possibility of animals shielding one another from the smoke when huddled together was investigated as follows.

Two rats were anaesthetized with urethane. They were placed together on a flat surface so that the nose and mouth of one were buried in the pectoral fur of the other; the two were held in position by a loop of string. They were exposed to $1,190 \mathrm{mg} . / \mathrm{m}^{3}{ }^{3}$ of smoke for 90 minutes. The nasal passages, trachea, and lungs of the animal which had breathed the smoke direct were blackened. On its pectoral fur, through which the other rat had breathed, was a ring of smoke deposit denser than elsewhere on the body. No smoke was found anywhere in the respiratory system of the rat which had breathed through the fur.

A similar experiment was performed with two mice with similar results.

In another experiment the chamber atmosphere was sucked through a belt of guinea-pig fur, $2 \mathrm{~mm}$. wide, at right angles to the hairs; the smoke was completely filtered out by the fur.

Physical and Chemical Properties of Tetralin Smoke.-The smoke was entirely stopped by a Whatman No. 1 filter paper; this suggests that it consisted of aggregates of diameter not less than $0.5 \mu$. This was confirmed by examination of a sedimentation cell sample; most of the deposit consisted of fluffy aggregates and networks, the smallest particles visible being thin wisps a few microns long. Eighty per cent of the smoke passed through the cascade impactor (May, 1945), most of the remainder being deposited elsewhere than on the slides. 
To measure the bulk density of the deposit, smoke was sucked through a Whatman No. 1 filter paper at an air velocity of $1.1 \mathrm{~cm}$./ $/ \mathrm{sec}$., and the weight and thickness of the deposit were noted. The bulk density was found to be between 0.03 and 0.04 ; the bulk density of soot scraped from the walls of the chamber was about 0.015. The deposit contained about $4.6 \%$ of tarry matter.

Changes in the $p \mathrm{H}$ of liquids when smoke deposit was added to them were investigated to see whether the smoke had any acid content which might account for its action on guinea-pigs, a species which may be fatally affected by sulphuric acid mist in concentrations as low as $12 \mathrm{mg} . / \mathrm{m}^{3}$; and also because city smokes appear to have a buffering action which interferes with estimations of acids in fog.

When $1 \mathrm{~g}$. of smoke deposit was added to $50 \mathrm{ml}$. of $25 \%$ ethyl alcohol (a liquid which wets the deposit) at $p \mathrm{H} 7$, the $p \mathrm{H}$ was hardly altered. The $p \mathrm{H}$ of a similar mixture containing $1 \mathrm{mg}$. of sulphuric acid to $50 \mathrm{ml}$. of liquid was 3.4 ; this rose to 3.6 when $1 \mathrm{~g} . / 50 \mathrm{ml}$. of smoke was added. It is thus clear that the effects of the smoke cannot have been due to its acid content, and that the buffering action of this particular smoke in the acid range is slight. At pH9 the smoke showed feebly acidic properties; $1 \mathrm{~g}$. neutralized about $10^{-4}$ mole of alkali.

\section{Discussion}

Toxicity of Black Smoke.-The figures displayed in Table 1 show that the $(\mathrm{Ct}) \mathrm{D} 50$ s for mice and guinea-pigs are of the same order of magnitude; the values for the heavier mice are rather larger than those for the smaller mice. The value estimated for rats is of the same order.

In the experiments with mice in which there were survivors, 27 died in the chamber, one died five minutes after removal, and 22 survived. This suggests that the $\mathrm{L}(\mathrm{Ct}) \mathbf{5 0}$ for mice is only a little (perhaps $1 \%$ ) less than the $(\mathrm{Ct}) \mathrm{D} 50$. The same probably holds for rats, in which similar lesions occur.

In guinea-pigs the lesions are different, and delayed deaths much commoner. Assuming a value of $\mathbf{8}$ for the slope of the graph of probit of total mortality against log. dosage, one may estimate the $\mathrm{L}(\mathrm{Ct}) 50$ for guinea-pigs as about $116,000 \mathrm{mg} . / \mathrm{m} .{ }^{3}$, or $75 \%$ of the $(\mathrm{Ct}) \mathrm{D} 50$; this accords with the fact that in experiment 3 the $\mathrm{L}(\mathrm{Ct}) 30$ was probably slightly less than the $(\mathrm{Ct}) \mathrm{D} 10$. Apart from the animals which died during or within 24 hours of the experiment, there were no deaths within one month of exposure.

The results suggest that animals allowed to associate together protect one another against the smoke; this is probably due to their huddling together and their fur acting as a filter. No explanation can be given of the very high slope found in experiment 2 , when 11 out of 25 associating mice died within half an hour.

In the mice and rats the lethal effects of the smoke appear to be due to blockage of the air passages by carbon particles, or by a secretion induced by them; it seems likely that low-density aggregates can be retained in the lung by an interception mechanism, in spite of their low impactability (May, 1945) as compared with droplets of similar size. The apparently smaller toxicity to the more mature mice used in experiment 2 and to the rats may be due to less easy blockage of the air passages in these animals.

In the guinea-pigs the haemorrhagic lesions and the late deaths leave no doubt that the effect of the smoke is of a different kind. They suggest that the smoke acts as a direct irritant to the air passages causing bronchial spasm, with attendant increased negative intrathoracic pressure. This leads to capillary haemorrhage and compensatory emphysema, so that irreversible damage is done to the lung without serious external signs.

The lesions in guinea-pigs resemble those produced by sulphuric acid mist, but the experiments on the chemical properties of the smoke show that its actual acid content is negligible.

Application to Atmospheric Pollution.-Both black smoke and sulphur dioxide have been blamed for the lethal quality of fog, and are the only pollutants whose concentrations in the London fog of 1952 are known; it is therefore of interest to compare the acute toxicity of tetralin smoke, as measured in these experiments, with that of sulphur dioxide in similar concentrations. This has been done in Table 2 .

The $\mathrm{L}(\mathrm{Ct}) 50$ s for tetralin smoke acting on mice and guinea-pigs have been estimated above. Weedon, Hartzell, and Setterstrom (1939) found that when guinea-pigs and mice were exposed to sulphur dioxide in concentrations varying from 170 to 3,000 mg. $/ \mathrm{m}^{3}, 33 \%$ of the total deaths caused took place after the animals had been removed from the gas. Late deaths were about as common among mice as among guinea-pigs. We may, therefore, suppose that a dosage which kills $33 \%$ of the animals during the exposure will afterwards kill a further $17 \%$, i.e., we may equate the $(\mathrm{Ct}) \mathrm{D} 33$ with the $\mathrm{L}(\mathrm{Ct}) 50$. Values of the (Ct)D 33 have been obtained from the data of Weedon et al. (1939), and from the records of Pattle and Burgess (1957), and are given in Table 2 as the $\mathrm{L}(\mathrm{Ct}) 50$.

It will be seen that judged by the $\mathrm{L}(\mathrm{Ct}) 50 \mathrm{~s}$, tetralin 
TABLE 2

DOSAGE AND EFFECTS OF SOME ATMOSPHERIC POLLUTANTS

\begin{tabular}{|c|c|c|c|c|}
\hline Pollutant & Animal & $\left(\mathrm{mg} \cdot / \mathrm{m} .^{3}\right)$ & $\mathrm{L}(\mathrm{Ct}) 50$ (mg. $\left.\mathrm{min} . / \mathrm{m}^{3}{ }^{3}\right)$ & Source \\
\hline $\begin{array}{l}\text { Tetralin smoke } \\
\text { Tetralin smoke } \\
\text { Combustion products of coal } \\
\text { Sulphur dioxide } \\
\text { Sulphur dioxide } \\
\text { Sulphur dioxide } \\
\text { Sulphur dioxide } \\
\text { Sulphur dioxide }\end{array}$ & $\begin{array}{c}\text { Mouse } \\
\text { Guinea-pig } \\
\text { Rat } \\
\text { Mouse } \\
\text { Mouse } \\
\text { Mouse } \\
\text { Guinea-pig } \\
\text { Guinea-pig }\end{array}$ & $\begin{array}{c}735 \text { to } 1,140 \\
500 \text { to } 1,070 \\
57 \\
800 \\
2,560 \\
2,430 \\
797 \\
2,800\end{array}$ & $\begin{array}{c}146,000 \text { to } 348,000 \\
116,000 \text { to } 153,000 \\
>4,200,000 \\
2,160,000 \\
1,030,000 \\
579,000 \\
3,460,000 \\
1,535,000\end{array}$ & $\begin{array}{l}\text { Current work } \\
\text { Current work } \\
\text { Vintinner and Baetjer (1951) } \\
\text { Weedon et al. (1939) } \\
\text { Pattle and Burgess (1957) } \\
\text { Weedon et al. (1939) } \\
\text { Weedon et al. (1939) } \\
\text { Pattle and Burgess (1957) }\end{array}$ \\
\hline $\begin{array}{l}\text { City smoke } \\
\text { Sulphur dioxide }\end{array}$ & $\begin{array}{l}\text { Man } \\
\text { Man }\end{array}$ & $\begin{array}{l}4.46(\max .)(b) \\
3.8 \text { (max.) }\end{array}$ & $\begin{array}{l}23,400 \text { (a) (b) } \\
19,600 \text { (a) }\end{array}$ & $\begin{array}{l}\text { Scott (1953) } \\
\text { Scott (1953) }\end{array}$ \\
\hline
\end{tabular}

(a) Mortality of order $0.1 \%$; dosages quoted are maxima.

(b) Estimated by stain method.

smoke is some 10 times more toxic to mice, and some 25 times more toxic to guinea-pigs, than is sulphur dioxide in similar concentrations.

Scott (1953) records the concentrations of smoke and sulphur dioxide at County Hall, London, in the London fog of 1952. The smoke concentrations were measured by stain blackness, a method which is subject to errors due to variation in the composition of the smoke. On the assumption that these data are accurate, the total dosages available to a person who stayed in the open at County Hall during the whole five days (December 5 to 9, 1952) of the fog have been calculated and are given in Table 2. It will be seen that the dosage of smoke available was greater than that of sulphur dioxide. In the smog there was thus more London smoke than sulphur dioxide, while tetralin smoke is more toxic to animals than is sulphur dioxide. It would, however, be unsafe to regard this as an indication that smoke was the main toxic agent in the 1952 smog, for city smoke differs in composition from tetralin smoke, and the concentrations in the toxicity experiments were much higher than those in the smog. The particles in a smoke as dense as that used in the experiments are also bound to form aggregates, even if their initial size is similar to that of particles in city smoke; many of the particles in the latter resemble carbon black (Cartwright et al., 1956). Moreover, sulphur dioxide sometimes has a bronchoconstrictive effect on human beings in concentrations as low as 1 p.p.m. $\left(2.7 \mathrm{mg} . / \mathrm{m}^{3}\right)$, while there is no evidence that tetralin smoke in this concentration has any effect. It is not therefore possible to draw any conclusions from the animal experiments in relation to the London smog, save that black smoke from burning tetralin, in dosages similar to those of London smoke available in the $1952 \mathrm{smog}$, has no detectable acute effect on animals.

This paper is reproduced with the permission of the Controller, H.M. Stationery Office.

\section{REFERENCES}

Bliss, C. I. (1937). [With Appendix by W. L. Stevens.] Ann. Applied Biology, 24, 815 .

Cartwright, J., Nagelschmidt, G., and Skidmore, J. W. (1956). Quart. J. roy. met. Soc., 82, 82 .

Claisse, P., and Josué, O. (1897). Arch. Méd. exp., 9, 205.

May, K. R. (1945). J. Sci. Instrum., 22, 187.

Meetham, A. R. (1952). Atmospheric Pollution, 1st ed., pp. 134 and 158. Pergamon Press, London.

Pattle, R. E. (1958). Proc. roy. Soc. B., 148, 217.

- , and Burgess, F. (1957). J. Path. Bact., 73, 411.

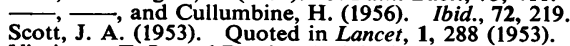

Vintinner, F. J., and Baetjer, A. (1951). A.M.A. Arch. industr. Hyg., 4, 206.

Weedon, F. R., Hartzell, A., and Setterstrom, C. (1939). Contr. 